\title{
Identification of Factors Influencing the Evacuation Walking Speed in Padang, Indonesia
}

\author{
Yosritzal \\ Civil Engineering Department \\ Andalas University \\ Padang, Indonesia \\ yosritzal@eng.unand.ac.id \\ H Putra \\ Information Technology Faculty \\ Andalas University \\ Padang, Indonesia \\ hasdiputra@fti.unand.ac.id
}

\author{
B M Kemal \\ Civil Engineering Department \\ Andalas University \\ Padang, Indonesia \\ badrul.m.kemal@gmail.com \\ Erick Mas \\ Associate Professor IRIDeS \\ Tohoku University \\ Sendai, Japan \\ mas@irides.tohoku.ac.jp
}

\author{
Purnawan \\ Civil Engineering Department \\ Andalas University \\ Padang, Indonesia \\ purnawan@eng.unand.ac.id
}

\begin{abstract}
This paper aims to identify factors influencing the walking speed of evacuees by conducting an evacuation drill in Padang, West Sumatera, Indonesia. A number of 18 volunteers and 6 observers, were gathered in an evacuation experiment on 3 routes with 5 segments each. The chosen routes are almost equal in terms of distance, but different in terms of the number of turning points. The experiment comprises of three cases in terms of the complexity of the route. These cases represent a simple, a medium and a complex route based on the number of turning points. The volunteers were asked to move, as if in an evacuation, to a particular place which was assumed to be a shelter. The observers were placed at some particular waypoints to record the time when an evacuee passes their location. The distance between the observers was measured using a manual distance meter. This study found that the average walking speed during the evacuation was $1.69 \mathrm{~m} / \mathrm{s}$. In addition, walking speed varied by age, gender, and walking distance. This finding significantly has an effect on the estimations of the coverage area of tsunami shelters. The data collection method is one of the novelties of this research. In this study, the walking speed was observed through an evacuation drill from a location to a shelter of 1.5 km away, whilst most of the previous studies estimate the walking speed based on an observation of a group of pedestrians crossing a road.
\end{abstract}

Keywords: tsunami, evacuation, walking speed, evacuation drill, Padang

\section{INTRODUCTION}

Padang is the capital of West Sumatera Province, Indonesia. Located close to the Ring of Fire in the west part of Sumatera Island. Padang has a substantial tsunami hazard potential, as reported by various authors such as [1], [2], [3], and [4]. The population of the city was about 914.968 in 2016 [5], and about half of them are living in the tsunamivulnerable area [6]. Many massive earthquakes had hit the area, and some of those had triggered significant tsunamis to the west coastal area of Sumatera Island and nearest islands such as Mentawai and Nias Islands. Previously, on February 10, 1797, and November 24, 1833, tsunami was reported with a respectively $5 \mathrm{~m}$ and 3-4 $\mathrm{m}$ inundation high of tsunami [3]. Padang is predicted to face up to $15 \mathrm{~m}$ tsunami inundation shortly [7], [8], [9], [3]. McCloskey reported that an accumulation of a vast seismic moment deficit since 1797 and 1833 at the megathrust [3].

In order to reduce the disaster risk, the Indonesian government has been developing tsunami early warning systems, increasing the capacity of tsunami evacuation routes, building new or retrofitting existing buildings for temporary evacuation sites, and educating people about tsunami and evacuation [9], [10]. Given the complexity of the preparation and limited time and budget available, the Major of Padang was calling any contribution from the universities and experts (Personal communication, April 19, 2016). This paper is one of our contributions to answer the call.

This paper presents an observation of walking speed of evacuees during an experiment of tsunami evacuation in Padang. The objective of the study is to investigate the effects of the characteristics of the evacuation route and characteristics of evacuees on the evacuation walking speed. In particular, turning points in evacuation routes and age of evacuees. It is more valuable to measure the evacuation time with a much larger group of participants, however, in this area, it is difficult to invite people to do evacuation drill. It used to be at least once a year, the community-wide tsunami drill being organized by the government. However, in recent days, not so many people engage in the drill. Therefore, a limited evacuation drill should be organized to obtain the required data. This study is the extension of our previous study published in [6], which observed the walking speed of the evacuees in a simple evacuation route (case 1 in this paper). Here, two more routes with different characteristics were added together with nine additional volunteers.

The walking speed during an evacuation is one of the most critical variables in developing evacuation plans [11], [12], [13]. Many studies have been aimed to estimate the walking speed in case of disaster evacuation, but almost all of the studies estimate is based on an observation of pedestrians at a crosswalk which is short in distance and not in evacuation cases [14]. In our study, the distance, duration, and route were set to be equal to the real situation; therefore this is one of the contributions of our study to the literature. 


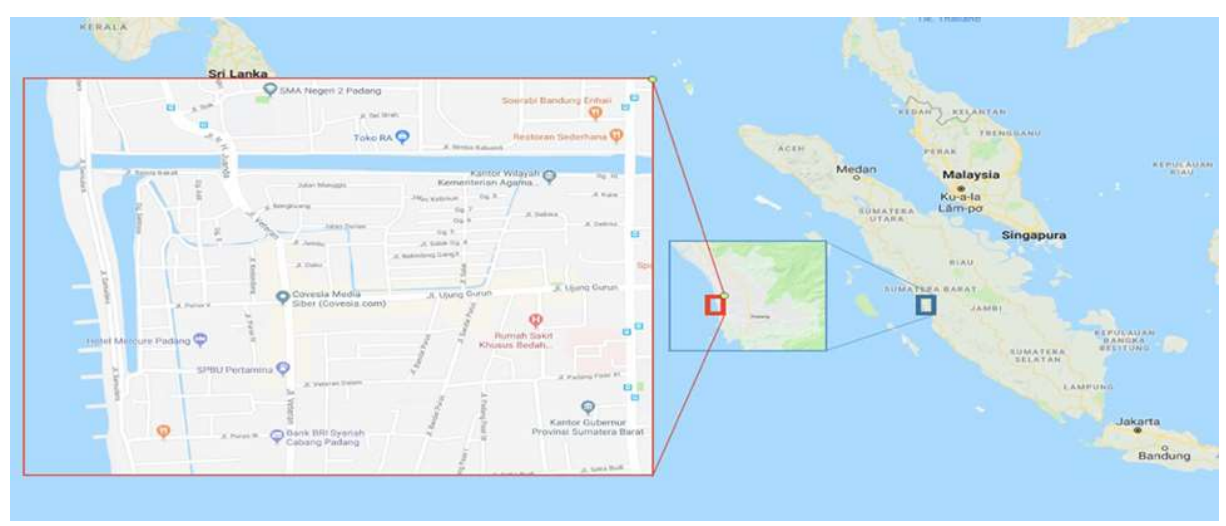

Fig. 1. Map of Case Study Location in Padang City.

\section{LITERATURE REVIEW}

\section{A. The Feature of Padang City}

Padang is one of the largest cities in Indonesia. Serving as the capital city of West Sumatera Province, Padang is located between $0^{\circ} 44^{\prime}$ and $01^{\circ} 08^{\prime}$ South Latitude and $100^{\circ} 05^{\prime}$ and $100^{\circ} 34^{\prime}$ East Longitude [5]. Cedillos et al. [7] reported that the terrain of Padang is flat within $3-4 \mathrm{~km}$ from the coast with elevation from zero up to five meters above sea level and then rising toward hills further inland. The map of Padang is shown in Fig. 1.

The authorities in Padang are advising people to evacuate on foot immediately after the suspected tsunami-generating earthquake hit [15]. Furthermore, people have also been suggested to leave their cars and bring only a bag with emergency stuff inside [15]. The evacuation was suggested to be done to the nearest shelters or the safety zones [16]. The use of a car is possible to make evacuation more difficult due to traffic jam and bottleneck [17]. Learning the preferences of car users in parking their car, [18] found that the majority of respondents prefer to park on the street. Parking on the street will make the evacuation routes become more vulnerable to a massive traffic jam during the evacuation. However, in reality, only a few people do evacuation immediately after a big earthquake hit the city, such as on September 30, 2009. Most people tried to find information on whether the earthquake triggered tsunami or not. The evacuation was started in 15 to 20 minutes after the earthquake, and most of them used their car and motorcycle.

The authorities have been setting some multi-story buildings as shelters. People who might fail to reach the safety zone using horizontal evacuation would be an appeal to conduct a vertical evacuation to the nearest shelter. However, panic during previous earthquakes in Padang caused congestion in all of the tsunami evacuation routes. Everybody did horizontal evacuation using their cars, but none of them could pass through the traffic and reach the safety zone within the available evacuation time [19].

The government has been educating people using religious words since the Aceh's tsunami in 2004, which was used in many countries during the earthquake in Japan to provoke emotions of the people to make it easier for them to understand the situation [20]. However, no evaluation has been done to investigate the impact.

\section{B. Walking Speed Studies}

Walking speed studies are usually conducted in traffic engineering studies such as simulation of pedestrian movement in a corridor, sidewalk, or crosswalk [21], [22], [23], [24]. Sharifi et al. [21] investigated the walking behavior of individuals with disabilities through controlled video tracking. Iryo-Asano and Alhajyaseen [22] investigated the behavior of pedestrian at signalized crosswalks under uncongested conditions. Bosina and Weidmann [23] compared many walking speed studies and determined the variables that influence the walking speed. Paschalidis et al. [24] studied the behavior of pedestrians when crossing an intersection and examined parameters affecting the walking speed adaptation. However, the behavior of pedestrian movement during a non-disaster conditions would be different from an evacuation condition.

\section{Walking Speed in Disaster Mitigation Studies}

Yosritzal et al. [9] used the average walking speed of pedestrians in non-disaster conditions as a variable in estimating the coverage area of shelter. The same data was used in [25] and [10] in estimating coverage area, demand, and the estimation of the capacity versus demand of a shelter. Given that the effective available evacuation time has been estimated at around 17 minutes, the walking speed will limit the distance that could be reached by an evacuee. Using average walking speed in non-disaster conditions, [9] assumed that the average distance that could be reached by an evacuee was $1.37 \mathrm{~km}$.

Yosritzal et al. [9] found that the tsunami arrival time at shoreline was 37.1 minutes, slightly slower than [26], which was 35 minutes. Effective evacuation time was estimated at 17.1 minutes, which corresponds to a $1.37 \mathrm{~km}$ walk distance. This walking speed is similar to [27] whose found $1.3 \mathrm{~m} / \mathrm{s}$ for adults and $1.5 \mathrm{~m} / \mathrm{s}$ for children. Using this walking distance, [10] found the suggested area for horizontal evacuation. Some of the areas are overlapping between the horizontal evacuation safe zone and vertical evacuation. Yosritzal et al. [10] and [25] found that many parts of Padang City could not be covered by any of the evacuation plans. Therefore, [10] and [25] suggested preparing more 
shelters to increase the possibility of saving the people in the areas.

Abustan [28] recorded the average walking speed by observing people crossing at a crosswalk area and used his findings as a parameter in simulating a tsunami evacuation. The study found that the average walking speed of Malaysian is $1.16 \mathrm{~m} / \mathrm{s}$. The slowest is $1.04 \mathrm{~m} / \mathrm{s}$ and belongs to senior female adult, and the fastest is $1.38 \mathrm{~m} / \mathrm{s}$ and belongs to a male adult.

Wood et al. [29] estimated minimum walking speed of people in the vulnerable area in order to reach shelter before the tsunami wave reach the shoreline, instead of estimating the coverage area of shelter. Wood et al. [29] suggested different minimum travel speed to evacuate from hazard zone for each type of walking such as impaired adult $(0.89$ $\mathrm{m} / \mathrm{s})$, slow walk $(1.10 \mathrm{~m} / \mathrm{s}$, fast walk $(1.52 \mathrm{~m} / \mathrm{s})$, slow run $(1.79 \mathrm{~m} / \mathrm{s})$ and fast run $(3.85 \mathrm{~m} / \mathrm{s})$ depending on the evacuees' decision to start evacuation, their distance to the safety zone and the minimum available evacuation time. In this context, the decision to start evacuation is playing an important role.

An experiment of the evacuation of a water-related disaster was reported in [30]. The study found that the slope and age groups of participants influence the walking speed. The average speed at a flat surface was recorded that in 5 minutes, a group of participants can walk $741 \mathrm{~m}$ while on the steepest path with $15^{\circ}$ a group of participants can walk 460 $\mathrm{m}$ distance in 5 minutes.

Regarding the start time of evacuation, Sugimoto et al. [31] argue that in general, people start evacuation at different times. Therefore, in their simulation model, [31] divided the population into several groups and assigned a different start time for each group. Mas et al. [11] developed tsunami departure curves from questionnaire surveys to characterize the start time of evacuees during simulation. Sato et al. [20] suggest that the delays of resident starting evacuation were caused by psychological factors such as cognitive dissonance and attitudes waiting for a warning. Yosritzal et al. [10] assumed the evacuation starts in 20 minutes after the strong earthquake hit. This assumption may be too high even though current experience showed that it is more likely to be true. For example, earthquake September 1, 2017, in Padang, the majority of people tend to wait for instruction from the authorities, which were hard to receive as the electric power was shut down. A similar experience has also been reported regarding the September 31, 2009 earthquake in Padang, as noted by [32]. Most studies assumed that the institutional decision time is 5 minutes, and institutional notification time is 3 minutes. Nevertheless, the information will not be received until 20-25 minutes after the earthquake occurred as communication and information were lost by the power cut or damaged by the earthquake. Yunarto and Sari [32] assumed that the reaction time of people is 7 minutes; therefore the evacuation is started 15 minutes after the earthquake. Post et al. [33] wrote that the people reaction time is between 5-15 minutes, therefore the evacuation could be started in 13 to 23 minutes.

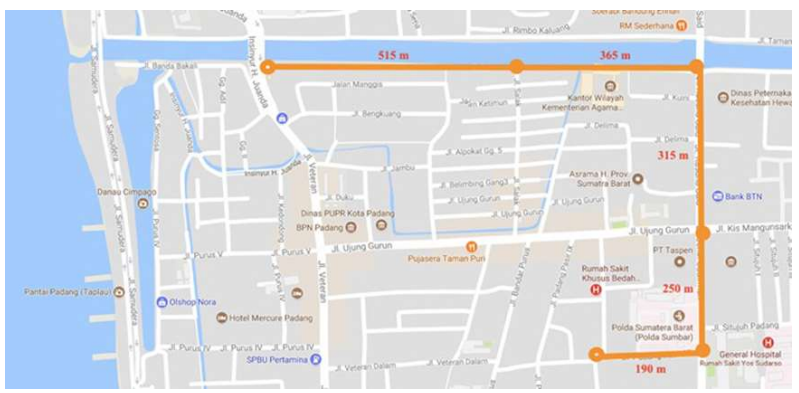

(a)

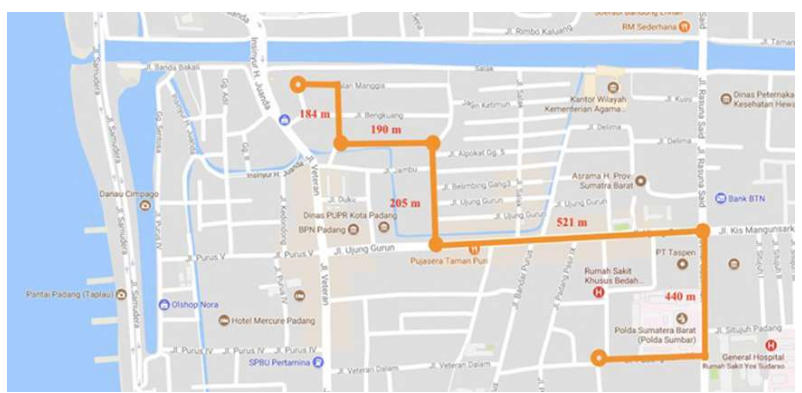

(b)

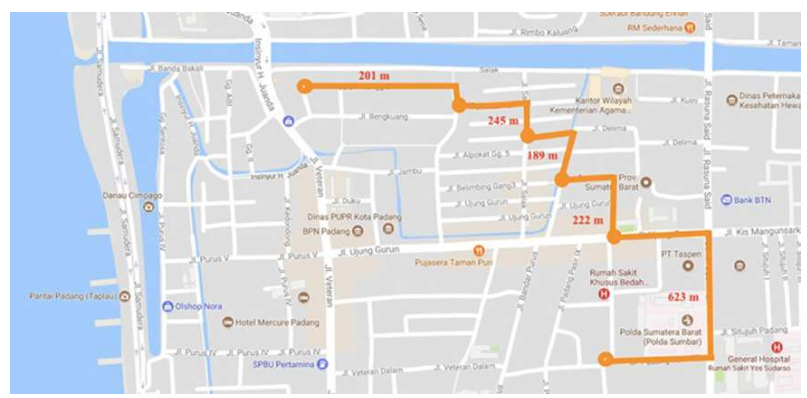

(c)

Fig. 2. The Simulated Routes: (a) Route 1 for scenario 1, (b) Route 2 for scenario 2, (c) Route 3 for scenario 3.

\section{Methodology}

The previous study suggested that the maximum walking speed varies by age and gender, but none of the studies examined the effect of walking duration or walking distance and the complexity of the route [28]; [29]. Therefore, in this study, in addition to age and gender, it was hypothesized that the maximum walking speed would be influenced by the duration of the walk and the complexity of the route.

Data for this study was obtained through an evacuation drill on October 29-30, 2017. The tsunami evacuation routes were set to start from a densely populated residential location to a shelter. There were three scenarios in the evacuation drill, which were based on the complexity of the route. The complexity of the route was simplified by assuming the more turning points along the route, the more complex the route. The chosen routes are shown in Fig. 2a, Fig. 2b, and Fig. 2c. The first scenario was examined the walking speed of volunteers (hereafter will be called evacuee) at the simple route which may not be the shortest path to the shelter, but it is relatively easy and safe for the 
volunteers. This route has two right turns and no left turn, and it is following an inspection road which is $5 \mathrm{~m}$ wide and then turns right through a major road with pedestrian footpath and then turns right again to the shelter. The starting point was chosen as the farthest point based on the estimated distance could be walked within 17 minutes; the effective available evacuation time [25].

Based on the distance measured by the google map application, the distance is around $1.6 \mathrm{~km}$. In the second scenario, Evacuees walked through a middle complex route, which has six turning points. The distance is about $1.5 \mathrm{~km}$, and the path is following a quite wide local street in a residential area. The route in the third scenario is more complicated, with ten turning points and passing narrower streets in the housing area.

Observers were placed at 6 points along the routes (marked as orange dots along the route) to observe the time when the Evacuees pass through their position. The Evacuees were asked to do a hurry walking from a specified point to a specified point near to a shelter. Evacuees recorded the time when they were passing each observer point using a stopwatch application on their mobile phone. The timing data recorded by a volunteer was used as the primary data and data observed by observers was used as a back up in case the volunteers fail to record their timing. Prior to the evacuation drill, volunteers were asked to sign a consent letter that they are willing to involve in the evacuation drill.

\section{RESUltS AND DisCUSSION}

\section{A. Characteristic of the Volunteers}

We invited 21 Volunteer to act as evacuees and six volunteers as observers for the evacuation drill. Evacuees were asked to walk through a particular route for about 1.5 to $1.6 \mathrm{~km}$ distance. Evacuees under ten years old should be accompanied by one adult. There were three evacuees under ten years old involved in this study; therefore 3 of the adults will be the companion of the children, and their data will not be considered in the analysis. The final data will be based on the 18 evacuees' data, where some of them involved in more than one scenario. In the case of evacuee involved in more than one scenario, 1-hour time was given to take a rest before engaging in the next evacuation drill scenario. The profile of the sample is shown in Fig. 3.

Fig. 3a shows that, in terms of age, most of the Evacuees are in the second group with an age interval between 20 to 40 years old. In terms of gender, Fig. $3 \mathrm{~b}$ shows that male is about $60 \%$ and female is $40 \%$. There are five segments of the simulated route, as shown in Fig. 4, which observed by one observer each. The distances between the segments in Route 1 are $515 \mathrm{~m}, 365 \mathrm{~m}, 315 \mathrm{~m}, 250 \mathrm{~m}$, and $190 \mathrm{~m}$ respectively, whilst in Route 2 are 184 m, 190 m, 205 m, 521 $\mathrm{m}$, and 440 m, and in Route 3 are $201 \mathrm{~m}, 245$ m, 189 m, 222 $\mathrm{m}$, and $623 \mathrm{~m}$ as shown in Fig. 2.

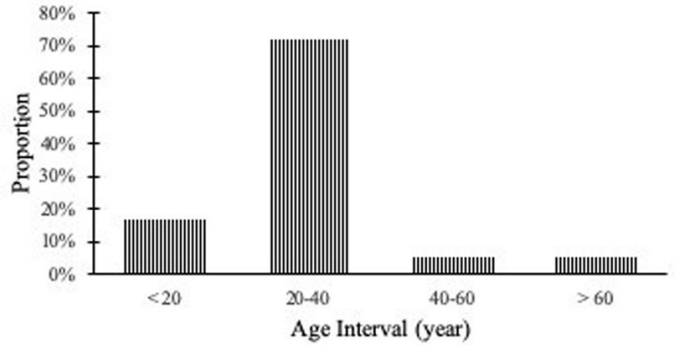

(a)

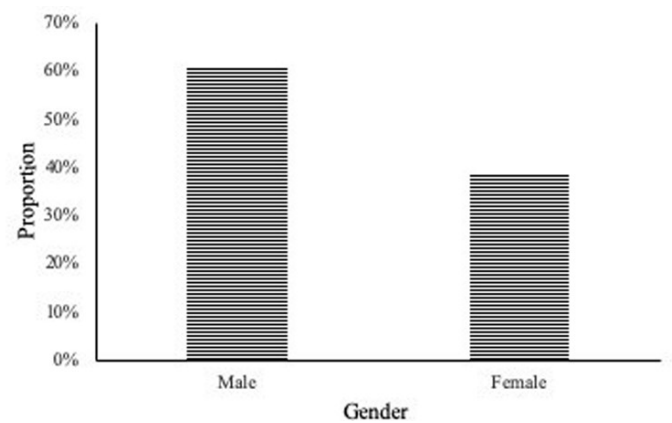

(b)

Fig. 3. Distribution of Evacuees: (a) by age interval and (b) by gender.

\section{B. Walking Speed by Route and Age Group}

In general, it was found that, on average, the walking speed of all participants was $1.70 \mathrm{~m} / \mathrm{s}$. Data on the average walking time and speed among the age group interval is shown in TABLE I to III. It can be seen in the Tables that the walking speed of the evacuees was varying by age group and by the segment of the route. In Route 1, there were no Evacuees in the age group of 40-60 years old involved. The mean walking speed of those who are in the age group up to 10 years old was $1.35 \mathrm{~m} / \mathrm{s}$. The mean walking speed for the age group 20-40 years old was $1.51 \mathrm{~m} / \mathrm{s}$ while the age group $>60$ years old was $1.40 \mathrm{~m} / \mathrm{s}$. However, the standard deviations of the up to 20 and $>60$ groups are much more significant than the $20-40$ group $(0.24 \mathrm{~m} / \mathrm{s}$ and $0.37 \mathrm{~m} / \mathrm{s}$ respectively compared to $0.05 \mathrm{~m} / \mathrm{s}$ ). Overall the average walking speed was $1.42 \mathrm{~m} / \mathrm{s}$. In the second and third scenario, there were no children under ten years old involved. In Route 2, the mean of walking speed for age group 20-40 years old was $1.84 \mathrm{~m} / \mathrm{s}$ while the age group of $40-60$ and $>60$ years old were 1.61 and $1.55 \mathrm{~m} / \mathrm{s}$, respectively.

TABLE I. Distribution OF THE AVERAge WALKING Time AND SPEED AT ROUTE 1

\begin{tabular}{|l|l|c|c|c|c|c|c|}
\hline \multirow{2}{*}{ No. } & \multirow{2}{*}{$\begin{array}{c}\text { Distance } \\
(\mathbf{m})\end{array}$} & \multicolumn{2}{|c|}{$\begin{array}{c}\text { Average Walking } \\
\text { Time by Age Group } \\
\text { (minute) }\end{array}$} & \multicolumn{3}{c|}{$\begin{array}{c}\text { Average Walking } \\
\text { Speed by Age Group } \\
(\mathbf{m} / \mathbf{s})\end{array}$} \\
\cline { 3 - 8 } & & $<\mathbf{2 0}$ & $\mathbf{2 0 - 4 0}$ & $\mathbf{8 6 0}$ & $<\mathbf{2 0}$ & $\mathbf{2 0 - 4 0}$ & $>\mathbf{6 0}$ \\
\hline 1 & 515 & 6.11 & 5.59 & 7.00 & 1.40 & 1.54 & 1.23 \\
\hline 2 & 365 & 3.72 & 3.90 & 3.00 & 1.64 & 1.56 & 2.03 \\
\hline 3 & 315 & 5.33 & 3.68 & 4.00 & 0.98 & 1.43 & 1.31 \\
\hline 4 & 250 & 2.93 & 2.77 & 3.00 & 1.42 & 1.50 & 1.39 \\
\hline 5 & 190 & 2.44 & 2.11 & 3.00 & 1.30 & 1.50 & 1.06 \\
\hline Average & & & 1.35 & 1.51 & 1.40 \\
\hline
\end{tabular}


TABLE II. Distribution OF THE AVERAge WALKING Time AND SPEED AT ROUTE 2

\begin{tabular}{|l|l|l|l|l|l|l|l|}
\hline \multirow{2}{*}{ No. } & \multirow{2}{*}{$\begin{array}{c}\text { Distance } \\
(\mathbf{m})\end{array}$} & \multicolumn{2}{|c|}{$\begin{array}{c}\text { Average Walking Time } \\
\text { by Age Group } \\
\text { (minute) }\end{array}$} & \multicolumn{3}{|c|}{$\begin{array}{c}\text { Average Walking } \\
\text { Speed by Age Group } \\
\text { (m/s) }\end{array}$} \\
\cline { 3 - 8 } & & $\mathbf{2 0 - 4 0}$ & $\mathbf{4 0 - 6 0}$ & $\mathbf{7 0}$ & $\mathbf{2 0 - 4 0}$ & $\mathbf{4 0 - 6 0}$ & $>\mathbf{6 0}$ \\
\hline 1 & 184 & 1.42 & 1.72 & 2.00 & 2.16 & 1.78 & 1.53 \\
\hline 2 & 190 & 1.82 & 2.07 & 2.00 & 1.74 & 1.53 & 1.58 \\
\hline 3 & 205 & 1.81 & 2.10 & 2.00 & 1.89 & 1.63 & 1.71 \\
\hline 4 & 521 & 4.75 & 5.40 & 6.00 & 1.83 & 1.61 & 1.45 \\
\hline 5 & 440 & 4.57 & 4.88 & 5.00 & 1.60 & 1.50 & 1.47 \\
\hline \multicolumn{2}{|l|}{ Average }
\end{tabular}

TABLE III. Distribution OF THE AVERAge WALKing Time AND SPEED AT ROUTE 3

\begin{tabular}{|l|l|l|l|l|l|l|l|}
\hline \multirow{2}{*}{ No. } & \multirow{2}{*}{$\begin{array}{c}\text { Distance } \\
(\mathbf{m})\end{array}$} & \multicolumn{3}{|c|}{$\begin{array}{c}\text { Average Walking Time } \\
\text { by Age Group } \\
\text { (minute) }\end{array}$} & \multicolumn{3}{c|}{$\begin{array}{c}\text { Average Walking Speed } \\
\text { by Age Group } \\
\text { (m/s) }\end{array}$} \\
\cline { 3 - 8 } & & $\mathbf{2 0 - 4 0}$ & $\mathbf{4 0 - 6 0}$ & $\mathbf{7 6 0}$ & $\mathbf{2 0 - 4 0}$ & $\mathbf{4 0 - 6 0}$ & $>\mathbf{6 0}$ \\
\hline 1 & 201 & 2.49 & 2.98 & 2.00 & 0.81 & 0.67 & 1.01 \\
\hline 2 & 245 & 2.17 & 2.50 & 3.00 & 1.13 & 0.98 & 0.82 \\
\hline 3 & 189 & 1.66 & 2.03 & 2.00 & 1.14 & 0.93 & 0.95 \\
\hline 4 & 222 & 2.05 & 2.30 & 3.00 & 1.08 & 0.97 & 1.20 \\
\hline 5 & 623 & 6.16 & 5.50 & 7.00 & 1.01 & 1.13 & 0.89 \\
\hline \multicolumn{7}{|l|}{ Average } \\
\hline
\end{tabular}

It can be seen that the average walking speed for the Route 2 is higher than the walking speed at Route 1 and Route 3 across all of the age groups. Route 1, as the most straightforward route, was expected to be walked faster than any other routes. However, the study found that walking speed in Route 1 is slower than Route 2, which was more complicated. After carefully assessing the route, we found that the difference between Route 1 and Route 2 is that Route 1 is disturbed by traffic and the route is lack of shade to avoid the sun.

\section{Walking Speed over Time}

In order to investigate the influence of the walking duration to the walking speed, average walking speed was differentiated by routes and segments. Given the available data was limited, the analysis was focusing on the age group 20-40 years old.

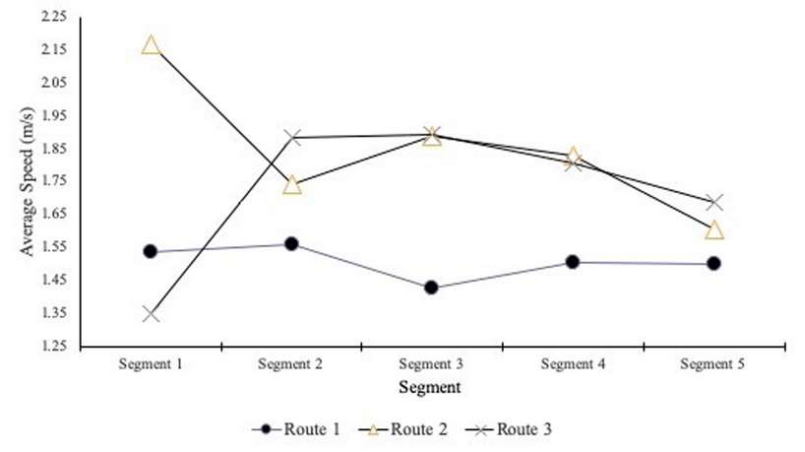

Fig. 4. The Average Walking Speed from Segment to Segment.

The result is presented in Fig. 4. Despite different walking speeds were emerged at different segments and routes, a trend pattern can be seen that the walking speed was reduced over time. As the segments are sequential, and the evacuees walked continuously from segment 1 to segment 5 , it is understood that the walked duration and distance increases from segment 1 to segment 5 . This finding should be considered when estimating the coverage area of a shelter because the tsunami wave velocity might not have the same feature.

\section{Walking Speed by Gender}

When the walking speed of males and females being compared, the walking speed of males was found to be $10 \%$ higher than females as shown in TABLE IV. In this case, only males and females at the 20-40 age interval groups being compared. The average walking speed of males and females were $1.60 \mathrm{~m} / \mathrm{s}$ and $1.45 \mathrm{~m} / \mathrm{s}$, respectively.

TABLE IV. Comparison Walking Speed of Male and Female

\begin{tabular}{|l|l|l|l|l|l|}
\hline \multirow{2}{*}{ No. } & \multirow{2}{*}{$\begin{array}{c}\text { Distance } \\
(\mathbf{m})\end{array}$} & \multicolumn{2}{|c|}{$\begin{array}{c}\text { Average Walking } \\
\text { Time by Gender } \\
\text { (minute) }\end{array}$} & \multicolumn{2}{c|}{$\begin{array}{c}\text { Average Walking } \\
\text { Speed by Gender } \\
(\mathbf{m} / \mathbf{s})\end{array}$} \\
\cline { 3 - 6 } & & Male & Female & Male & Female \\
\hline 1 & 515 & 5.20 & 5.86 & 1.65 & 1.46 \\
\hline 2 & 365 & 3.57 & 4.12 & 1.70 & 1.48 \\
\hline 3 & 315 & 3.37 & 3.88 & 1.56 & 1.35 \\
\hline 4 & 250 & 2.82 & 2.73 & 1.48 & 1.53 \\
\hline 5 & 190 & 1.94 & 2.22 & 1.63 & 1.43 \\
\hline \multicolumn{2}{|l}{ Average } & & 1.60 & 1.45 \\
\hline
\end{tabular}

\section{E. Comparison with Previous Studies}

The findings of this study are slightly higher than [27] and much higher compared to [28]. However, Rienne et al. [27] observed walking speed in building evacuation drill, and [28] observed walking speed at a crosswalk as a representation of walking speed during a tsunami evacuation. We believe that the use of walking speed at a crosswalk in estimating the walking speed during evacuation such as in Abustan [28] may lead to bias as the pedestrian might not in a hurry when crossing the road.

Our finding shows that the walking distance may have influenced the average walking speed. In a short distance, [27] found that children were faster compared to adults than in a long-distance. It is expected that for a shorter distance, children tend to walk in a rush whilst adult tend to walk at their normal speed. Nevertheless, further investigation is needed to justify the hypothesis.

\section{CONClusions}

This paper presents the result of an experiment of tsunami evacuation in Padang, West Sumatera, Indonesia. The study found that the average walking speed during the experiment was $1.70 \mathrm{~m} / \mathrm{s}$. The walking speed differs by age group and gender. Those who are in the age group $20-40$ years old were found to walk $11 \%$ faster than young children and $7 \%$ faster than the elder groups. Male was found to be $10 \%$ faster than female at the same age group. As the evacuees were ordered to walk in a hurry, the profile of the walking is higher than previous studies on walking speed of pedestrians on a normal day. The walked distance is more likely to influence the walking speed while the number of turning points is still not clear. This finding has a significant 
influence on the estimation of the coverage area of shelter and may be used in evacuation modelling. Further, to be more realistic, our plan is to do evacuation drill of participants in groups.

\section{REFERENCES}

[1] Borrero, J. C., Sieh, K., Chlieh, M., and Synolakis, C. E. (2006), "Tsunami inundation modeling for western Sumatra", P. Natl. Acad. Sci. USA, 103, 19673-19677, https://doi.org/10.1073/pnas.0604069103, 2006

[2] McCaffrey, R. (2007), "The next Great Earthquake", Science, Vol. 315, pp. 1675-1676.

[3] McCloskey, J., Antonioli, A., Piatanesi, A., Sieh, K., Steacy, S., Nalbant, S., Cocco, M., Giunchi, C., Huang, J. D. and P. Dunlop (2008), "Tsunami threat in the Indian Ocean from a future megathrust earthquake west of Sumatra", Earth and Planetary Science Letters, Vol. 265, Issues 1-2, pp. 61-81.

[4] Schlurmann, T., Kongko W., Goserberg, N., Natawidjaja, D.H., and Sieh, K. (2010) "Near-field tsunami hazard map Padang, West Sumatera: Utilizing high-resolution geospatial data and reasonable source scenarios" Coastal Engineering.

[5] BPS (2016), Population and Growth Rate of Population by District in the Padang City, 2010, 2015, and 2016 (in Indonesian). Retrieved at 20 July 2018 from https://padangkota.bps.go.id/dynamictable/2017/07/14/157/jumlahpenduduk-dan-laju-pertumbuhan-penduduk-menurut-kecamatan-dikota-padang-2010-2015-dan-2016-.html.

[6] Yosritzal, Kemal BM, Purnawan, Putra H. (2017a), "An Observation of the walking speed of evacuees during a simulated tsunami evacuation in Padang, Indonesia", IOP Conf. Series: Earth and Environmental Science 140 (2018) 012090. DOI: 10.1088/17551315/140/1/012090.

[7] Cedillos V, McAdoo B G, Muhari A, and Natawidjaja D H. (2010), "An Evaluation of Infrastructure for Tsunami Evacuation in Padang, West Sumatera, Indonesia", Proceedings of the 9th U.S. National and 10th Canadian Conference on Earthquake Engineering Juli 25-29, 2010 Vancouver, Canada, 2010.

[8] Muhammad A, Goda K, Alexander N A, Kongko W, and Muhari A. (2017), "Tsunami Evacuation Plans for Future Megathrust Earthquakes in Padang, Indonesia Considering Stochastic Earthquake Scenarios" Nat. Hazards Earth Syst. Sci., 17, 2245-2270, 2017, https://doi.org/10.5194/nhess-17-2245-2017.

[9] Yosritzal, Kemal B K, and Siddik F. (2016), "Estimation of the coverage area of tsunami shelters in Padang", Proceeding of National Conference of Applied Sciences, Engineering, Business, and Information Technology Politeknik Negeri Padang 15-16 Oktober 2016.

[10] Yosritzal, Kemal B M, and Aulia Y B. (2017b), "Demand versus capacity of tsunami shelters in Padang, Indonesia", International Journal of Advanced Science Engineering Information Technology Inpress Manuscript was submitted and accepted for publication in 2017.

[11] Mas E, Imamura F, Koshimura S. Modelling the Decision of Evacuation from Tsunami based on Human Risk Perception Tohoku Branch Annual Meeting Sendai Japan Society of Civil Engineering (JSCE) 2011, 2011.

[12] Kim, Nam-Sook. (2016), "Successful Deriving Evacuation Factors of the Korean Aged", Indian Journal of Science and Technology Vol. 9(40). DOI: 10.17485/ijst/2016/v9i40/103277. ISSN (Print) : 09746846 ISSN (Online) : 0974-5645.

[13] Seike, M., Kawabata, N., Hasegawa, M., and Lu, Y. (2016), "Evacuation Speed Distribution By Full-Scale Tunnel Experiments", 8th International Conference "Tunnel Safety and Ventilation".

[14] Kiyono, J, and Mori, N. (2004), "Simulation of Emergency Evacuation Behaviour During A Disaster by Use of Elliptic Distinct Elements", 13th World Conference on Earth Engineering, Vancouver, B.C., Canada.

[15] BPBD (2010), Padang City Tsunami Evacuation Map (in Indonesian). Available at http://www.gitews.org/tsunamikit/en/E4/further_resources/evacuation_plan/padang/Peta\%20Evakuas i\%20Padang.pdf. Retrieved on 20 July 2018.
[16] Stanford (2009), "Conceptual Design of Infrastructure for Evacuation from Tsunami for Padang City, Indonesia", Final Report Stanford University 2009.

[17] Mas E, Adriano B, Koshimura S, Imamura F, Kuroiwa J H, Yamazaki F, Zavala C, and Estrada M. (2013), "Identifying Evacuees' Demand of Tsunami Shelters Using Agent-Based Simulation", Book Chapter, Tsunami Events and Lessons Learned Vol 35 of the series Advances in Natural and Technological Hazards Research, 2012 pp 347-358 Springer.

[18] Yaldi, G., I. M. Nur, Apwiddhal, and Momon. (2016), "Defining Suitable Parking Controls to Minimize Negative Impacts of Road Traffic: A Case Study in Padang City", International Journal on Advanced Science Engineering Information Technology Vol. 6. No. 5. ISSN: 2088-5334, 2016.

[19] Tribunews (2016), The Tsunami Evacuation Route in Padang was Totally Jammed (in Indonesian), Retrieved on 20 July 2018 from http://www.tribunnews.com/regional/2016/03/02/jalur-evakuasitsunami-di-padang-macet-total.

[20] Sato Y and Waragai I. (2017), "The Function of Religious Language in the Media: A Comparative Analysis of the Japanese, German and American Newspaper Coverage about the 2011 Great East Japan Earthquake and Tsunami”, International Journal on Advanced Science Engineering Information Technology Vol 7 (2017) No 2 ISSN: 20885334.

[21] Sharifi M S, Christensen K, Chen A, Stuart D, Kim Y S and Chen Y Q. (2017), "A large-scale controlled experiment on pedestrian walking behaviour involving individuals with disabilities", Travel Behaviour and Society 8 (2017) 14-25.

[22] Iryo-Asano M and Alhajyaseen W. (2017), "Consideration of a pedestrian speed change model in the pedestrian-vehicle safety assessment of signalised crosswalks", Transportation Research Procedia 21 (2017) 87-97.

[23] Bosina E and Weidmann U. (2017), "Estimating pedestrian speed using aggregated literature data", Physica A 468 (2017) 1-29.

[24] Paschalidis E, Politis I, Basbas S, and Lambrianidou P. (2016), "Pedestrian compliance and crosswalking speed adaptation due to countdown timer installations: A self-report study Transportation Research Part F 42 (2016) pp 456-467.

[25] Kemal BM, Yosritzal, Aulia Y B. (2017), "Evaluation of tsunami evacuation plans in Padang, Indonesia", International Journal of Civil Engineering and Technology (IJCIET) Volume 8 Issue 10 October 2017 pp 773-780.

[26] Honesti L, Majid M Z A, and Muchlian M. (2014), "Assessing Building Vulnerability of Tsunami Hazard in Padang", Jurnal Teknologi July 2014 DOI: 10.11113/jt.v69.3318.

[27] Rienne T, Tillander K, and Gronberg P. (2010), "Data collection and analysis of evacuation situations", Espoo 2010. VTT Tiedotteita Research Notes 2562.46 p. + app. 92 p.

[28] Abustan M S B H. (2013), "Numerical simulation of evacuation process against tsunami disaster in Malaysia by using distinctelement-method based multi-agent model", Ph.D. Dissertation at Kyoto University Japan, 2013.

[29] Wood N, Jones J, Schmidtlein M, Schelling J, and Frazier T. (2016), "Pedestrian Flow-path Modelling to Support Tsunami Evacuation and Disaster Relief Planning in the U.S. Pacific Northwest", International Journal of Disaster Risk Reduction Volume 18 September 2016 pp 41$55,2016$.

[30] Lee, JiSoo and Hong, Won-Hwa. Upward Evacuation Experiment for Estimating Evacuation Speed in Water Disaster. Advanced Science and Technology Letters Vo. 100 (Architec and Civil Engineering, 2015), pp. 97-101. http://dx.doi.org/10.14257/astl.2015.100.21, 2015.

[31] Sugimoto T, Murakami H, Kozuki Y and Nishikawa K. (2003), "A Human Damage Prediction Method for Tsunami Disasters Incorporating Evacuation Activities", Natural Hazards Vol 292003 pp 585-600.

[32] Yunarto, Y. and Sari, A.M. (2018), "Analysis of community tsunami evacuation time: An overview", IOP Conference Series: Earth and Environmental Science 118 (2018) 012033, 2018.

[33] Post, J., Wegscheider, S., Muck, M., Zosseder, K., Kiefl, R., Steinmetz, T., and Strunz, G. (2009), "Assessment of human immediate response capability related to tsunami threats in Indonesia at a sub-national scale", Natural Hazards and Earth System Science Vol 9, pp 1075-1086, 2009. 